\title{
Brain-Specific Angiogenesis Inhibitor 1
}

National Cancer Institute

\section{Source}

National Cancer Institute. Brain-Specific Angiogenesis Inhibitor 1. NCI Thesaurus. Code C26145.

Brain-specific angiogenesis inhibitor $1(1584 \mathrm{aa}, \sim 174 \mathrm{kDa})$ is encoded by the human ADGRB1 gene. This protein is involved in G protein-coupled receptor signaling and the inhibition of ang iogenesis. 